\title{
Introduction: The Episodes themed issue on Forensic Geology and the IUGS Initiative on Forensic Geology
}

Arup, $6^{\text {th }}$ Floor, 3 Piccadilly Place, Manchester, M1 3BN, UK; Chair, International Union of Geological Sciences, Initiative on Forensic Geology (IUGS-IFG); *Corresponding author,E-mail: Laurance.Donnelly@arup.com; geologist@hotmail.co.uk

(Received: November 23, 2016; Revised accepted: March 4, 2017)

http://dx.doi.org/10.18814/epiiugs/2017/v40i2/017011

This themed issue of 'Episodes' is dedicated entirely to forensic geology. This provides an overview of how geologists assist the police and law enforcement to help investigate crimes. The documented application of geology to police and law enforcement dates back to the middle part of the $19^{\text {th }}$ Century, and possibly to Roman times. Until the establishment of the International Union of Geological Sciences (IUGS), Initiative on Forensic Geology (IFG), in 2011, there was no international organization aimed at developing forensic geology on a global scale. Previously, forensic geologists worked in relative isolation from other fellow geologists. There were few incentives or opportunities for the advancement of forensic geology. IUGS-IFG has provided opportunities, incentives and the drive for the global development of forensic geology, as exemplified in this issue of Episodes.

\section{Episodes Themed Issue on Forensic Geology}

In 2016 the author was invited to produce, for the first time, a themed issue on forensic geology. This issue is therefore dedicated entirely to the subject of forensic geology. It has been divided into ten sections. Each provides an insight into the multi-disciplinary field of forensic geology. The authors have been carefully selected to represent a cross section of forensic geology applications. It has been written by geologists, geoscientists, police and law enforcement officers with many years' experience of the practical applications of geology to help investigate and solve crimes. This also serves to show case some of the advancement that have been made in forensic geology and the geological contributions to policing and law enforcement throughout the world.

Section 1 provides an introduction and context of the Episodes themed issue on forensic geology. Forensic geology is by no means a new subject since geologists have been advising the police, on certain types of criminal investigations, since the middle part of the $19^{\text {th }}$ Century. What is new however, is the globalization of forensic geology and the increasing recognition that geology can bring significant benefits to policing. Forensic geology also seemed to have captured the imagination of the pubic, media, students and crime writers who find the applications of geology to crime of interest and entertainment. Forensic geology is diverse and wide reaching. This includes the horror that can surround some forensic geology investigations to the intrigue and enthusiasm of students and the public. IUGS-IFG is aimed at developing and promoting forensic geology around the world. This issue of Episodes provides an insight into forensic geology and its applications to criminal investigations.

Section 2 discusses the applications of geology for ground searches relating to graves and other buried targets associated with homicide, terrorism and organized crime. This section discusses the history and background of ground searches and documents the emergence of a new and pioneering ground search strategy that developed over a period of approximately ten years, by combining typical police searches with conventional geological techniques. This includes a blended and collaborative methodology for the design and delivery of a high assurance, pragmatic and cost-effective ground search that is proportionate to the context of the buried target being sought.

Section 3 is relatively short but important account of the FBI laboratory experiences. This laboratory has examined soil and geological evidence since the 1930s. The results of these investigations have been admitted into courts in the USA and internationally. Soil evidence was not subject to a formal admissibility challenge within the USA courts system until 2016. This section discusses the examination of soil in the FBI and the comparison between a soil sample and a questioned sample to determine if they have a single common source. This is presented in the context of a trial (State of Kansas v. Kyle Flack, 13CR104, 2016) that included the admissibility of soil comparisons and the competence of the forensic geologist who was responsible for undertaking the soil examinations.

Section 4 provides an overview of the global developments in forensic geology, which has experienced somewhat of a renaissance in the past decade or so. The revival in interest in the application of geology to policing and law enforcement has been driven by several inter-related factors. One of the most pivotal and fundamental influences was the establishment of IUGS-IFG. This section provides an overview of how forensic geology has independently and simultaneously developed throughout the world. Within each region there are unique historical, political, social, anthropological, geological and law enforcement influences that have had a profound impact on how geology has been used to help investigate crimes throughout the world.

Section 5 provides an insight into the role of forensic geology in 
illegal and unlawful global trading of precious metals, diamonds and gemstones. The multi-million dollar trade in geological materials may be used as currency to pay for other illicit items and support criminal activities such as terrorism. A combination of geological expertise, robust data bases, reference samples, sophisticated state-of-the-art analytical techniques, and international collaboration enables the source of stolen precious metals to be identified and traced. Crime case examples are provided for gold and platinum-group metal theft in Africa.

Section 6 describes Predictive Geolocation. This is the application of forensic soil analysis for provenance determination. The forensic geological analysis of soils, rock fragments, microfossils and manmade materials derived from geological raw materials may be used to tests if there is an association between soil samples at a known geographical location, with soils recovered from exhibits or recovered from a suspect believed to be associated with a crime. Although soils are complex materials significantly influenced by geology, their geological variability can be used as a predictive tool to help determine the nature of the location that a soil was derived from and unknown location. This has been demonstrated in numerous operational cases relating to serious crimes including murders, grave location, rape cases, environmental crime and intelligence based investigations to determine a location visited by individuals of interest in a counter-terrorism context.

Section 7 demonstrates the powerful application of geological trace evidence to help solve five cases in Australia. This includes two murders, an attempt of murder, a cold case, and a sexual crime. Different geological materials were collected from questioned items that was believed by police to be associated with each crime, including soil on parts of vehicles, a spade, shoes and clothes. In one case, it took the soil forensic team two years to link microscopic brick particles found in a murder victims bra and hair to a particular type of brick in the yard at the front of the victim's house. In each case, control samples were also taken from the crime scene for comparison. The geological materials analysed comprised soils from a different of geo-environmental and sedimentological settings such as; coastal beaches, clay wetland, alluvium, and woodland. These were analysed using soils maps, mineralogy, pedology, and X-ray diffraction. Interestingly, other cases in Australia have been resolved without the need to conduct the forensic soil investigation, since the offenders confessed when they were informed by Police Detectives that soil samples have or will be collected by forensic soil scientists for investigation and comparison. Soil forensics may be used to verify if an individual may have been at a particular geographical location (or crime scene) they denied visiting.

Section 8 provides details of the organic characterisation of soil, which may be used in forensic geology in isolation or to corroborate the mineralogical analysis of soil. The forensic characterisation and analysis of soil has been shown to be of value for police and forensic investigations. Usually, an investigating officer may wish to determine where a sample of soil originated from, in other words what is its geological and geographical provenance. Alternatively, it may be desirable for the content of the questioned sample to determine whether there could be an association between two items or objects. Soils are composed of both inorganic and organic constituents. Using case examples this section focuses on the organic components of a soil and the non-destructive methods and techniques used to collect, analyse and characterise soils within a forensic context and for the provision of trace evidence.

Section 9 section draws attention to the applications of Geographical Information Systems (GIS) in forensic geoscience. GIS has advanced and developed significantly since the 1980s with software becoming increasingly more cost-effective. Although GIS has been used in crime density mapping, it is generally under utilised in forensic geoscience. IUGS-IFG has been promoting the applications of GIS in forensic geology. Using an example from IUGS-IFG training delivered with Australia Federal Police, this sections shows how GIS can provide a basis for planning, decision making, landscape modelling, and knowledge transfer associated with ground searches and crime scene examinations.

Section 10 provides a selection of international case examples where forensic geology has been applied to assist with a variety of interesting, and sometime unusual and bizarre fakes, fraud, homicide, and environmental crimes. One of the many challenges facing the development of forensic geology is the publication of operational case work. By their nature many of the cases investigated may be secret, restricted, sensitive, confidential, high profile or of a national and international media interest. However, this sections provides a representative collation of cases that have been granted permission for publication or that are already in the public domain.

\section{What is Forensic Geology?}

Forensic geology (also known as Forensic Geoscience or Geoforensics) is the application of geology to policing and law enforcement, which may potentially be applicable to a court of law. Forensic geology assist police and law enforcement in relation to: serious crimes (homicide, rape, and sexual assaults), organized crime, counter terrorism, kidnapping, humanitarian incidents, environmental crimes, wildlife crime, precious minerals and metals theft, fraudulent crimes, fakes, geohazards, geotechnical engineering, engineering geology, and ground searches for buried graves and other concealed items.

Generally, in a law enforcement context, forensic geologists may support the police in three ways, as follows:

- Ground searches for burials: These might be designed and implemented to locate homicide graves, mass graves related to genocide, weapons, firearms, improvised explosive devices, drugs and items of value (e.g., stolen items, money, coinage, jewellery, etc.). Ground searches may be protective or detective in nature and take place in urban, rural or remote locations, on land or in water. Generally, a search may be conducted to; (a) obtain evidence for prosecution, (b) gain intelligence, (c) deprive criminals of their resources and opportunities to commit crime or acts of terror, (d) locate vulnerable persons, (e) protect potential targets and venues, and (f) search for homicide graves and associated buried items or objects.

- Crime scene investigations: Geologists may be required to assist the police or forensic scientists at a crime scene to collect geological samples and provide specialized maps and interpretations of the soil, sediment, rocks, and man-made materials.

- Geological trace evidence: This involves collection, analysis, interpretation, presentation and explanation of geological evidence, often at a scene of crime or from an item or object, as intelligence 
and as evidence. Geological trace evidence includes; rock fragments, natural soils and sediments, artificial (anthropogenic) man-made materials derived from geological raw materials (such as bricks, concrete, glass or plaster board) or micro-fossils. Trace evidence may be transferred onto the body, person or the clothing of a victim or offender or onto vehicles or objects from and to a crime scene. This, when is interpreted by an experienced forensic geologist can help with crime reconstruction and may be admissible in a court.

\section{Early History}

Forensic geology is by no means new. Anecdotally, and according to legend, an examination of soil and rock fragments found in horse hooves assisted Roman soldiers in locating the camp of the enemy (personal communications, Rosa Maria Di Maggio). However, the documented applications of geology to assist with police and law enforcement investigations dates back to the middle part of the 19th Century, when Professor Christian Gottfried Ehrenberg (1795-1876) working in Berlin was able to identify the provenance of sand that had been used to substitute stolen silver being transported in barrels on a train in Prussia.

Hans Gross was a criminal investigator and professor of criminology working in Austria and published, in 1893, his Handbuch für Untersuchungsrichter (Handbook for Examining Magistrates). He noted that, "Dirt on shoes can often tell us more about where the wearer of those shoes had last been than toilsome inquiries". The application of the microscope enabled soil and rock fragments to be analysed to determine if there could be an association between items or objects that had been in contact with the ground at a crime scene.

George Popp was working in Germany in the early part of the 1900s. Eva Disch was murdered in 1904, she had been strangled with her own scarf. He analyzed nasal mucus on a handkerchief found at a crime scene. The fragments of coal, snuff, and hornblende crystals were consistent with materials found beneath the finger nails of a suspect. Popp subsequently investigated other murders using microscopic analysis (e.g., the Margarethe Filbert murder in Bavaria, 1908) and he how noted the stratigraphic layering of different soils on shoes could be used to build a profile of an offenders movements that showed he was present at a scene of crime. These cases were based on the Exchange Principal, devised by Edmond Locard who was working in France in the early 1900s, who developed the concept that, "every contact leaves atrace."

The writing of Conan Doyle and the fictitious work of Sherlock Homes, 1887-1927, made reference to the idea of soil analysis to help investigate crime. For example, the colour and consistency of splashes of mud on trousers helped Homes to identity what part of London Dr. Watson had been walking. Conan Doyle was possibly aware of Gross's work through the work of Campbell (2007) who shows in his book "Sherlock Holmes" on the story of "The Problem of Thor Bridge" that Doyle based this story on two sources, one of which was a faked German suicide related by Hans Gross in his book (personal communications, Alastair Ruffell).

In the 1930's, the Federal Bureau of Investigation (FBI) Laboratory analyzed soil and this was applied to a kidnapping case (The
Matson kidnapping) to identify where a victim had been prior to his murder. Today, the FBI laboratory continues to conduct research and operational case work.

In 1956, Walter McCrone Associates was launched in Chicago and used microscopy extensively for forensic geology and other (e.g., food, explosives, contamination, fraud) cases. One of McCrone's students later established Microtrace, a private trace evidence laboratory, and has successfully provided trace evidence for several high profile crimes including the Green River Murders.

Although used in criminal cases, no term was applied to the use of geological and soil evidence until publication of the most important text in this arena. Murray and Tedrow's (1975) classic textbook "Forensic Geology" combined a thorough basic training in geology with real cases. Updated several times by Raymond Murray (most recently as, "Evidence from the Earth, in 2011"), this book remains the fundamental starting point for all those interested in the subject.

In the UK, during the 1970 to 1980 s the Home Office at the Central Research Establishment, at Aldermaston, made significant advances in areas such as soil density gradient examination techniques, cathodoluminescence, colour analyses, and particle-size analysis. The Forensic Science Services (FSS) was set up in the early part of the $21^{\text {st }}$ Century as the Natural Justice Group and included forensic soils science and forensic geology services to police forces and Government departments in the UK. FSS closed in 2010 and in the past decade there has been an increase in private consultancies and universities carrying out forensic services.

Forensic geologists have also been involved in fake and fraud cases. Such as the Bre-X group of companies in Canada who reported that an enormous gold deposit has been discovered at Busang, Indonesia. Mineralogical analysis showed that different gold from another locality had been illegally and artificially introduced into samples to inflate the value of the assets. This discovery caused the collapse of Bre-X shares and revealed the biggest mining scam in history. Other fakes and fraud include rare fossils, diamond and precious gemstones, rare earth metals, metal theft, and the mineralogical analysis of paint to reveal art fraud (Fig. 1).
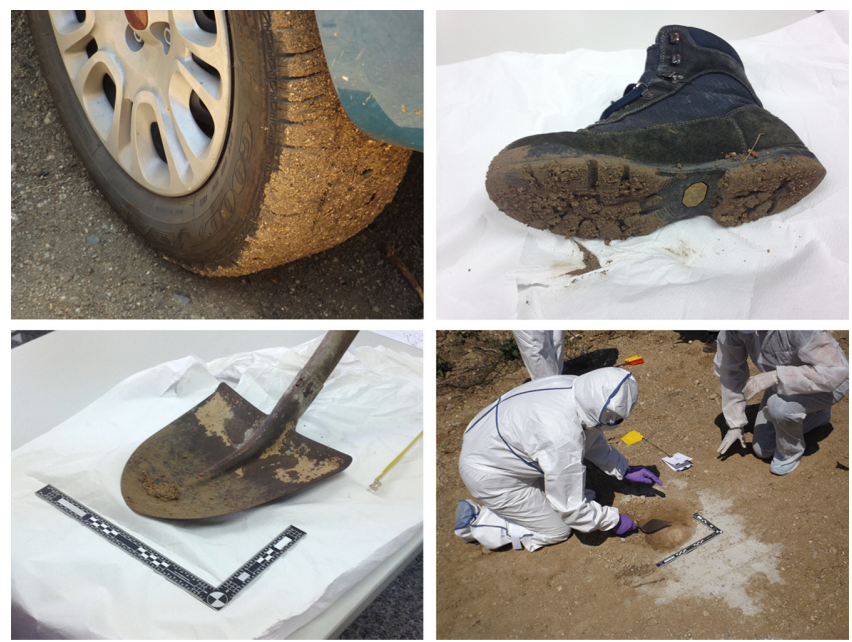

Figure 1. Soil, adhered onto various items and its forensic recovery (Photos: Laurance Donnelly and University of Messina, Sicily, Italy). 


\section{The Establishment of IUGS-IFG}

In the mid-1990s, the author began using geological methods to search for the grave of a child who the police suspected had been murdered and buried in a remote location in Europe. This included search strategies that were not conventionally used by the police, but were more common in mineral exploration or geotechnical ground investigations (Donnelly, 2003).

By the early 2000s, geologists had assisted the police in the UK with certain types of criminal investigation. However, the police and law enforcement officers are not conventionally trained in geology, and geologists were not familiar with police and crime scene protocols. There was a huge challenge ahead.

There were few opportunities for forensic geology to grow and advance. At this time the majority of forensic geologists in the world worked in relative isolation. There was no formal international collaboration between fellow forensic geology professionals. Research and teaching was not being conducted in academia. Publications were few and far between and there was little guidance on the practicable applications of forensic geology. The personal development of forensic geologists was limited. The discussion and publication of cases has always been problematic in forensic geology, balancing the need to maintain the confidentiality of ongoing sensitive case work, and at the same time the need to develop the forensic geology profession. There was no incentive or forum for the analysis of case work so that lessons and experiences could be learned.

In March 2002, the author accepted an invitation to give a presentation on The Moors Murders and Forensic Geology, at Westminster Palace, House of Commons, in London, as part of the All-Party Parliamentary Group for Earth Sciences (Donnelly, 2002). This was followed by a radio interview on the same subject for BBC Radio 4, also held in London. These events attracted much attention from other geologists, the police, media and some politicians. This began to highlight the need for specialist group on forensic geology.

From 2002 to 2005, a plan developed for the establishment of a new forensic geology group (Donnelly, 2005). The search for the last remaining Moors Murder victim was being conducted on of Saddleworth Moor in Northern England provided the opportunity for this new group to be discussed and for its aim and objectives to be determined. This was given further incentive by the first forensic geoscience conference held in London (Pye and Croft, 2004). On $22^{\text {nd }}$ November 2006, The Geological Society of London gave permission for a specialist group to be set up, as the Forensic Geoscience Group (FGG). The FGG inaugural meeting was held at the Geological Society of London, Burlington House headquarters on $18^{\text {th }}$ December 2006 (Donnelly, 2006).

The possibility for the first international working group on forensic geology was considered on $8^{\text {th }}$ and $9^{\text {th }}$ August 2008 during the $5^{\text {th }}$ Annual Business Meeting of the, "IUGS Commission on Geoscience for Environmental Management" (IUGS-GEM), in Oslo, Norway (Donnelly, 2008). This specialist focus group subsequently became established as the, "IUGS-GEM Working Group on Forensic Geology", in Montevideo, Uruguay, on $12^{\text {th }} \& 13^{\text {th }}$ October 2009 . Forensic Geology was one of several workings groups that also included; Dust, Gold and Mercury, Land Subsidence and Groundwater, Climate Change Adaptation,

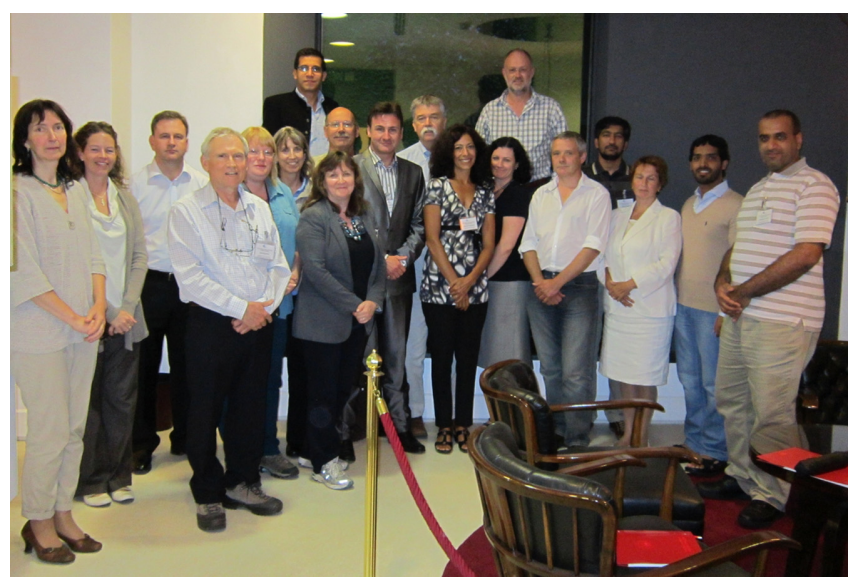

Figure 2. IUGS-IFG Committee Inaugural meeting in Rome, $19^{\text {th }}$ September 2011 (Photo: Laurance Donnelly).

Man-Made Strata and Geopollution, Drinking Water, and Geological Hazards and Territorial Sustainability. During the $6^{\text {th }}$ Annual Business Meeting of IUGS-GEM, held on $5^{\text {th }}$ October 2010 in Windhoek, Namibia, the IUGS-GEM Working Group on Forensic Geology was considered for promotion to an IUGS Initiative. IUGS Initiatives are informal, project-oriented activities organized under the Executive Committee with no prescribed structure, considerable freedom of operation, and no time limit on their duration.

The International Union of Geological Sciences (IUGS), launched the Initiative on Forensic Geology (IFG) at the $62^{\text {nd }}$ Executive Committee Meeting of the IUGS, which was held at UNESCO headquarters, in Paris, France, on $22^{\text {nd }}$ February 2011 (Donnelly, 2011). The IUGS-IFG inaugural meetings wad held in Rome on $18^{\text {th }}-19^{\text {th }}$ September 2011 (Fig. 2).

\section{Aim and Objectives}

The aim of IUGS-IFG is to promote and develop forensic geology throughout the world. The objectives of IUGS-IFG are to:

- Collate and disseminate data and information on forensic geology applied to policing and law enforcement, criminal, environmental and civil investigations;

- Promote international meetings, seminars, conferences and training;

- Develop a 'Committee' to act as principal advisers, collaborators and active participants;

- Develop an international network whereby each 'member' will act as a principal contact in their respective country for the collation and dissemination of information on forensic geology;

- Collate, make available and where appropriate review any existing documentation and publications in forensic geology; and

- Produce a document endorsed by the Committee to be called; "A Guide to Forensic Geology".

\section{Governance}

The principles of a non-profit organization are followed and upheld. The IUGS-IFG committee meets regularly to; hold outreach, knowledge exchange and capacity building events; professional train- 


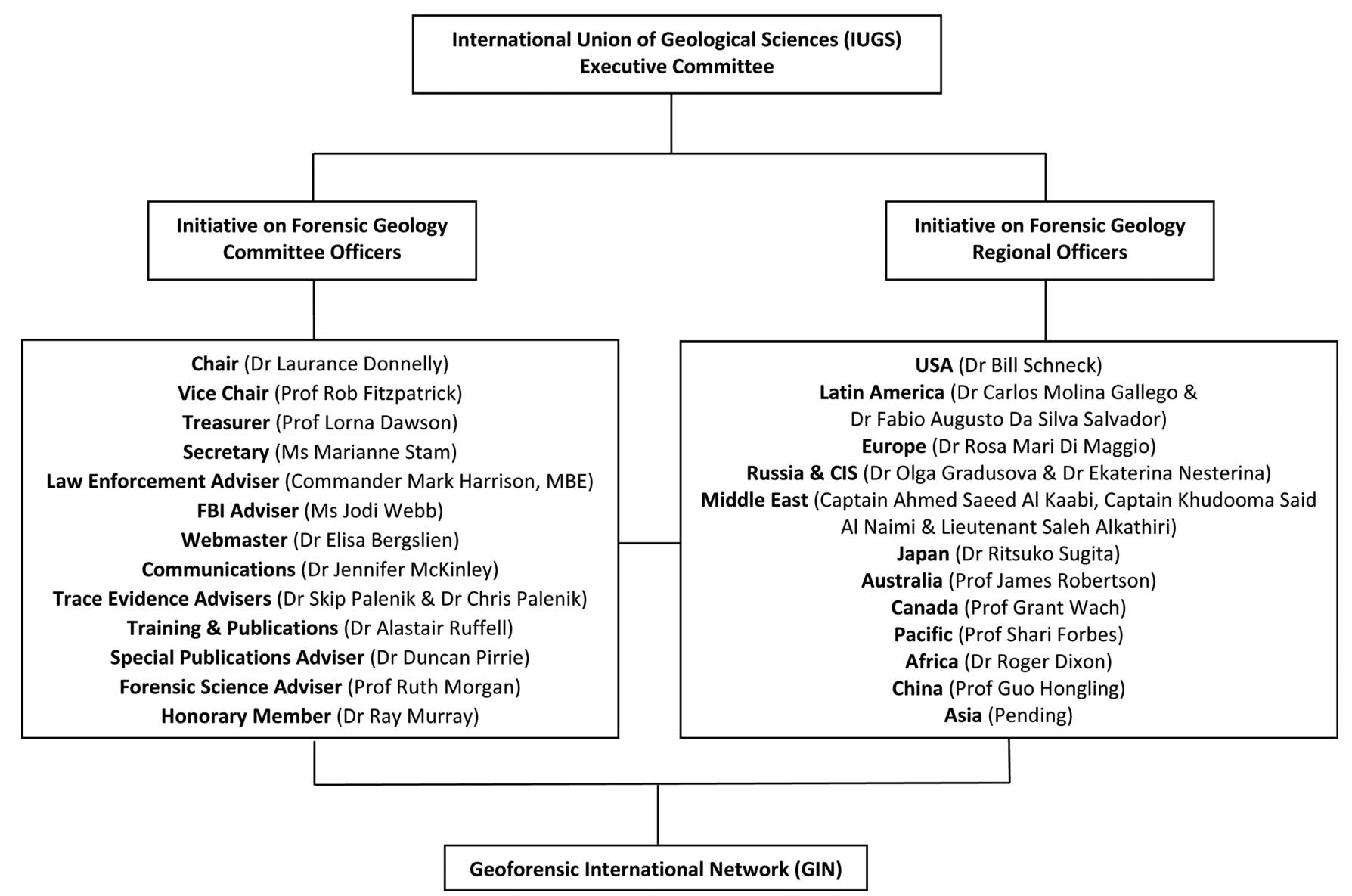

Figure 3. IUGS-IFG Committee and Structure.

ing, educational workshop and business meetings. Annual meetings and workshop are integrated with geoscientific conferences. This helps to maximize IUGS-IFG's outreach capability, professionally develop IUGS-IFG committee members and to facilitate the global development of forensic geology.

The IUGS-IFG Committee comprises representatives from major geographical regions of the world and includes specialists from academia, industry, consultancy, operationally based forensic geologists, the police, law enforcement agencies and forensic organizations (Fig. 3 and Table 1).

\section{Geoforensic International Network (GIN)}

The Geoforensic International Network (GIN) is part of IUGS-IFG. This brings together forensic geologists, geoscientists, police and law enforcement from around the world, who have a desire and interest in the development of forensic geology. Those countries now represented in GIN include; Australia, Argentina, Belgium, Brazil, Canada, China, Colombia, England, France, Germany, Hungary, India, Iran, Ireland, Italy, Japan, Malta, Mexico, Namibia, New Zealand, Nigeria, Northern Ireland, Poland, Portugal, Russia, Scotland, South Africa, Spain, Sweden, Switzerland, Netherlands, United Arab Emirates, United States of America, Wales and the West Indies (Caribbean).

\section{IUGS-IFG Overview}

From 2011 to 2016, IUGS-IFG organised, procured, managed and delivered approximately 170 events throughout the world. Generally, every two weeks somewhere in the world there was a forensic geology event held. These varied considerably from short focus meetings and presentations to the delivery of training or operational support.

A IUGS Ad Hoc Review Committee (ARC) was convened to review the progress of IFG. This mandatory review was held on $4^{\text {th }}$ April 2016, in Manchester, UK, under the Chairmanship of Prof Jose Calvo, Secretary General of IUGS. ARC concluded that during the period 2011-2016 IFG has met and exceeded its objectives. IUGS, via IFG, has provided the opportunity for the development and advancement of forensic geology throughout the world. This has resulted in this multidisciplinary science being firmly established in the geology profession, policing and law enforcement (Calvo, 2016).

Conventionally, IUGS-IFG events are categorised as; outreach, knowledge exchange and capacity building or training.

\section{Outreach}

The aim of outreach is to draw attention to forensic geology. IUGSIFG has engaged with a variety of stakeholders, this has included: police forces, law enforcement organisations, geological surveys, professional 
Table 1. IUGS-IFG committee members and their affiliations

\begin{tabular}{|c|c|c|c|}
\hline Position & Name & Country & Affiliation \\
\hline Chair & Dr. Laurance Donnelly & England (UK) & IUGS-IFG \& Arup, Manchester, England, UK \\
\hline Vice Chair & Prof. Rob Fitzpatrick & Australia & CSIRO, Australia \\
\hline Treasurer & Prof. Lorna Dawson & Scotland (UK) & The James Hutton Institute, Aberdeen, Scotland, UK \\
\hline Secretary & Ms. Marianne Stam & USA & California Department of Justice, Los Angeles, USA \\
\hline Webmaster/Information Officer & Dr. Elisa Bergslien & USA & SUNY Buffalo State, New York, USA \\
\hline $\begin{array}{l}\text { Geoforensic Law Enforcement } \\
\text { Adviser }\end{array}$ & Commander Mark Harrison, MBE & Australia & Australia Federal Police, Australia \\
\hline FBI Adviser & Dr. Jodi Webb & USA & Federal Bureau of Investigation (FBI), Virginia, USA \\
\hline Training and Publications & Dr. Alastair Ruffell & Northern Ireland (UK) & Queens University Belfast, Northern Ireland, UK \\
\hline Communications & Dr. Jennifer McKinley & Northern Ireland (UK) & Queens University, Belfast, Northern Ireland, UK \\
\hline Special Publications Adviser & Dr. Duncan Pirrie & England (UK) & Helford Geoscience LLP, Cornwall, UK \\
\hline Forensic Science Adviser & Prof. Ruth Morgan & England (UK) & $\begin{array}{l}\text { University College London, JDI Centre for the } \\
\text { Forensic Sciences, London, UK }\end{array}$ \\
\hline $\begin{array}{l}\text { Geological (Trace) Evidence } \\
\text { Advisers }\end{array}$ & $\begin{array}{l}\text { Dr. Skip Palenik } \\
\text { Dr. Chris Palenik }\end{array}$ & USA & Microtrace LLC, Illinois, USA \\
\hline Honorary Committee Member & Dr. Raymond Murray & USA & Forensic Geologist, Montana, USA \\
\hline Officer, USA & Dr. Bill Schneck & USA & Washington State Patrol Crime Lab \\
\hline Officer, Latin America & $\begin{array}{l}\text { Dr. Carlos Molina Gallego } \\
\text { Dr. Fabio Augusto Da Silva } \\
\text { Salvador }\end{array}$ & Colombia Brazil & $\begin{array}{l}\text { Instituto Nacional de Medicina Legal y Ciencias } \\
\text { Forense, Bogota, Colombia } \\
\text { Brazilian Federal Police, Curitiba, Brazil }\end{array}$ \\
\hline Officer, Europe & Dr. Rosa Maria Di Maggio & Italy & $\begin{array}{l}\text { Geoscienze Forensi Italia (Formerly Servizio Polizia } \\
\text { Scientifica), Rome, Italy }\end{array}$ \\
\hline Officer, Russia \& CIS & $\begin{array}{l}\text { Dr. Olga Gradusva } \\
\text { Dr. Ekaterina Nesterina }\end{array}$ & Russia & $\begin{array}{l}\text { Russian Federal Centre of Forensic Science, Ministry } \\
\text { of Justice, Moscow, Russia }\end{array}$ \\
\hline Officer, Middle East & $\begin{array}{l}\text { Captain Ahmed Saeed Al Kaabi } \\
\text { Captain Khudooma Said Al Naimi } \\
\text { Lieutenant Saleh Ali Al Katheeri }\end{array}$ & UAE & $\begin{array}{l}\text { Abu Dhabi Police, Forensic Evidence, } \\
\text { United Arab Emirates }\end{array}$ \\
\hline Officer, Japan & Ritsuko Sugita & Japan & National Research Institute of Police Science, Japan \\
\hline Officer, Australia & Prof. James Robertson & Australia & University of Canberra, Australia \\
\hline Officer, Pacific & Prof. Shari Forbes & Australia & University of Technology, Sydney, Australia \\
\hline Officer, Canada & Prof. Grant Wach & Canada & $\begin{array}{l}\text { Basin and Reservoir Lab, Dalhousie University, } \\
\text { Halifax, Nova Scotia, Canada }\end{array}$ \\
\hline Officer, Africa & Dr. Roger Dixon & South Africa & $\begin{array}{l}\text { University of Pretoria (Formerly, Forensic Science } \\
\text { Laboratory, South African Police Service), South Africa }\end{array}$ \\
\hline Officer, China & Dr. Guo Hongling & China & $\begin{array}{l}\text { Institute of Forensic Science, Ministry of Public } \\
\text { Security, Division of Trace Evidence Analysis, China }\end{array}$ \\
\hline
\end{tabular}

geological bodies, government departments, non-government organisations, co-professional and consultants. Both forensics science and geology seems to have gripped the imagination of the public and as a result have benefited by positive media and film attention in recent years. As such, IUGS-IFG committee members have carried out selected engagement with the media including TV, radio, and documentary entertainment programs, and crime fiction writers.

Public engagement and working closely with schools, colleges and universities are important to IUGS-IFG. General presentations on forensic geology have been provided for primary school children (aged 7 to 11). More scientific based presentations and some case work have been delivered to high school children (aged 11 to 16). In 2013, the International School Science Fair, held in Cornwall, England, IUGSIFG was involved in setting up a simulated crime scene. School children dressed in protective crime scene suites were able to conduct ground searches for (fake) nail bombs and weapons. They subse- quently collected soils samples from a vehicle, spade and clothing and the analysis of these soils provided geological evidence enabled them to help solve a fabricated crime (Pirrie et al., 2013) (Figs. 4 and 5).

More detailed presentations have been given to university students at BSc and MSc level. IUGS-IFG have collaborated with Ph.D. research students in both geological (trace) evidence and ground searches for burials. This has included the analysis of soils, leachate plumes and volatile organic compounds associated with human decomposition. This is based on case work and observations at the Department of Forensic Anthropology, University of Tennessee, Knoxville, Tennessee, USA. IUGS-IFG has also provided ideas for collaboration at Australian Facility for Taphonomic Experimental Research (AFTER). This facility is the first of its kind in Australia, and the only facility outside of the USA, that allows the donation of cadavers to study the process of human decomposition in a natural environment. Such facilities, often colloquially are referred to as, 'body farms'. 

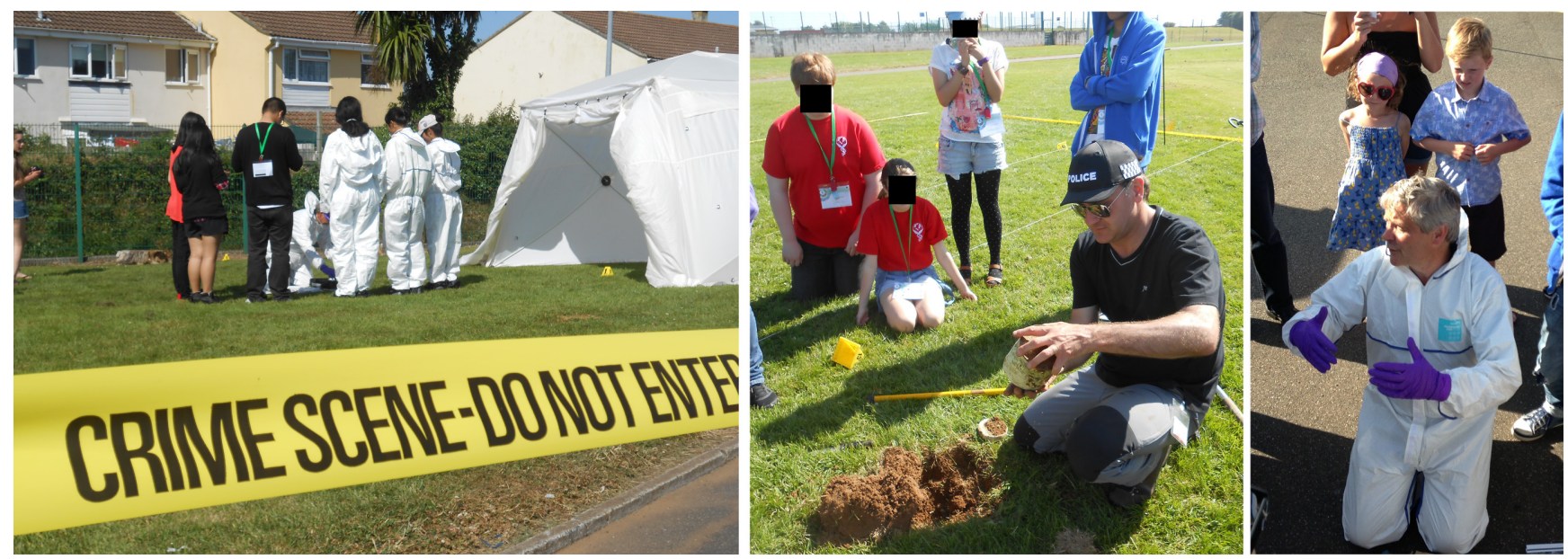

Figure 4. Students undergoing training in search and the collection of geological trace (Photos: Laurance Donnelly and Duncan Pirrie, in Pirrie et al., 2013).

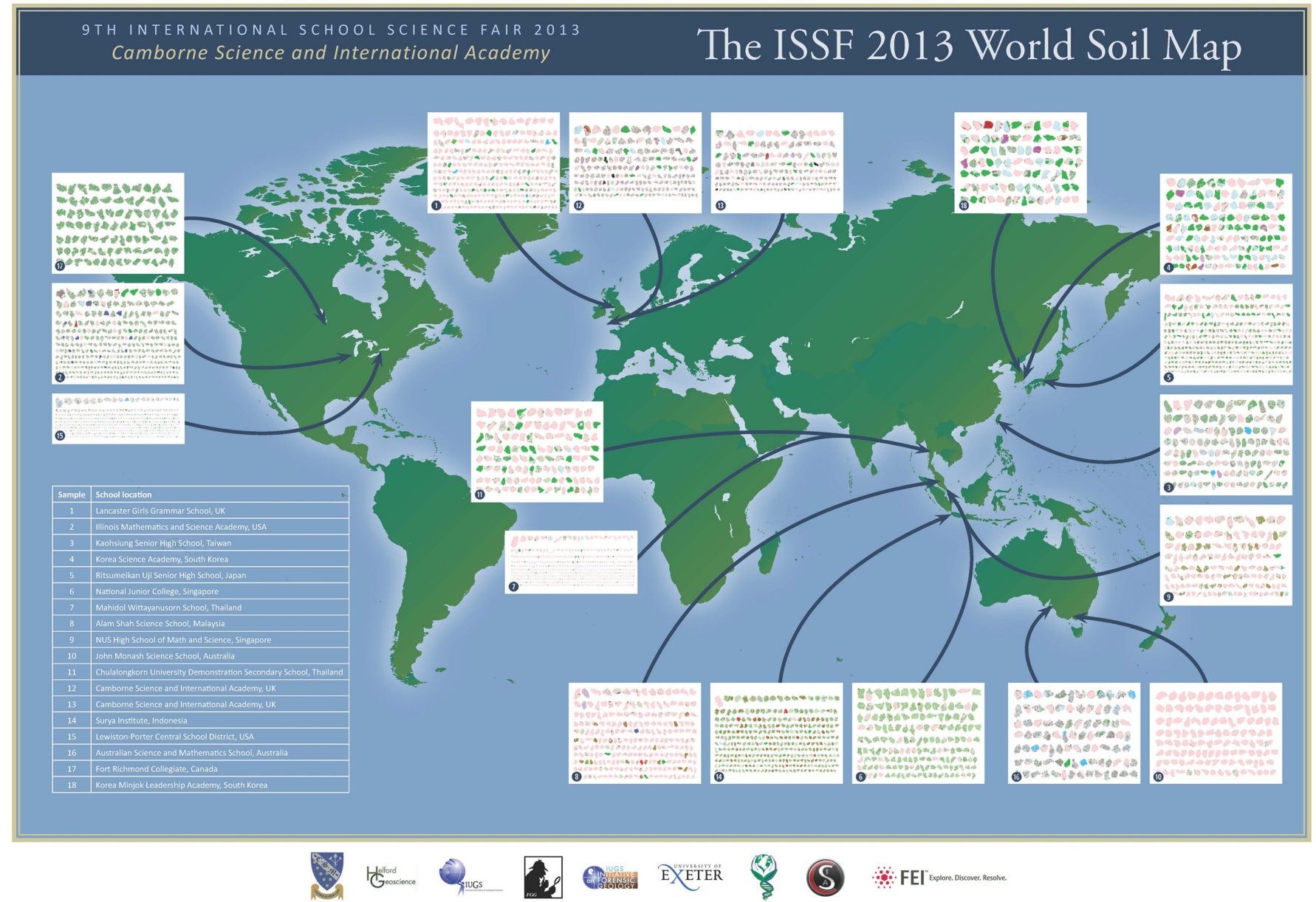

Figure 5. The IUGS-IFG and the International School Science Fair, World Soil Map, Cornwall, UK (Source: Pirrie et al., 2013, and IUGSIFG Annual Report for 2013).

\section{Knowledge Exchange and Capacity Building}

The aim of knowledge exchange and capacity building is to provide data, information, operational case work, best practice, methods, awareness, techniques and strategies with a small focus group. This teaching is provided to team leads, who seek to introduce forensic geology or improve the applications of forensic geology within their respective organisation. Knowledge exchange and capacity building events have been organized and delivered by IUGS-IFG in collaboration the several international federal police forces (Fig. 6). A soil forensics and forensic geology knowledge transfer event was organised by the IUGS-IFG and took place in Moscow, Russia, in 2013. This was 


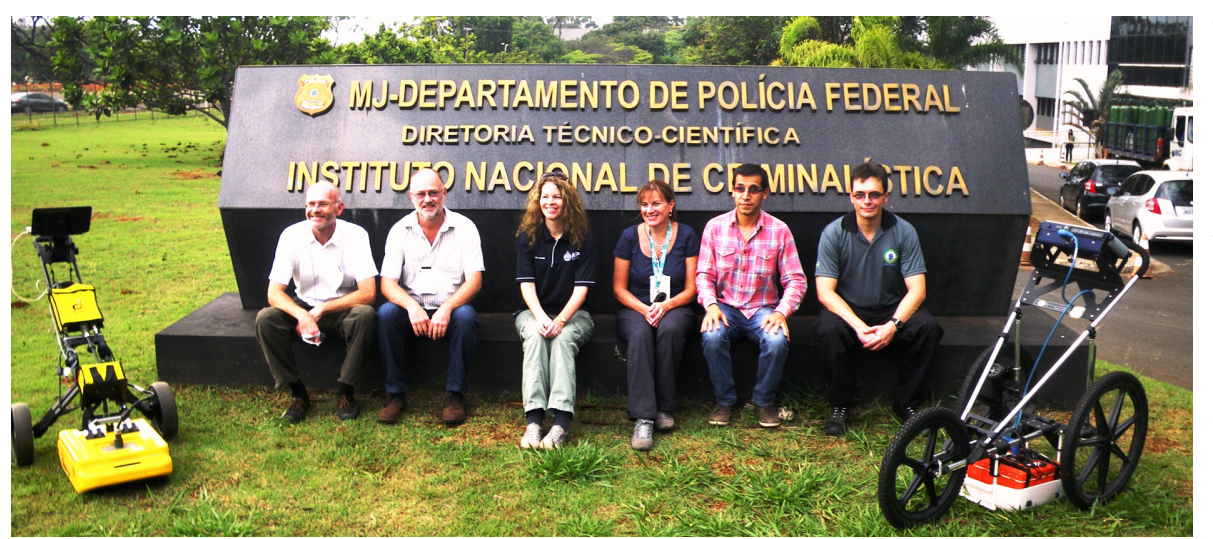

Figure 6. IUGS-IFG \& Brazilian Federal Police forensic geology workshop and training, Brasilia, Brazil, October 2013 and December 2015 (Source: IUGS-IFG Annual Report for 2013).

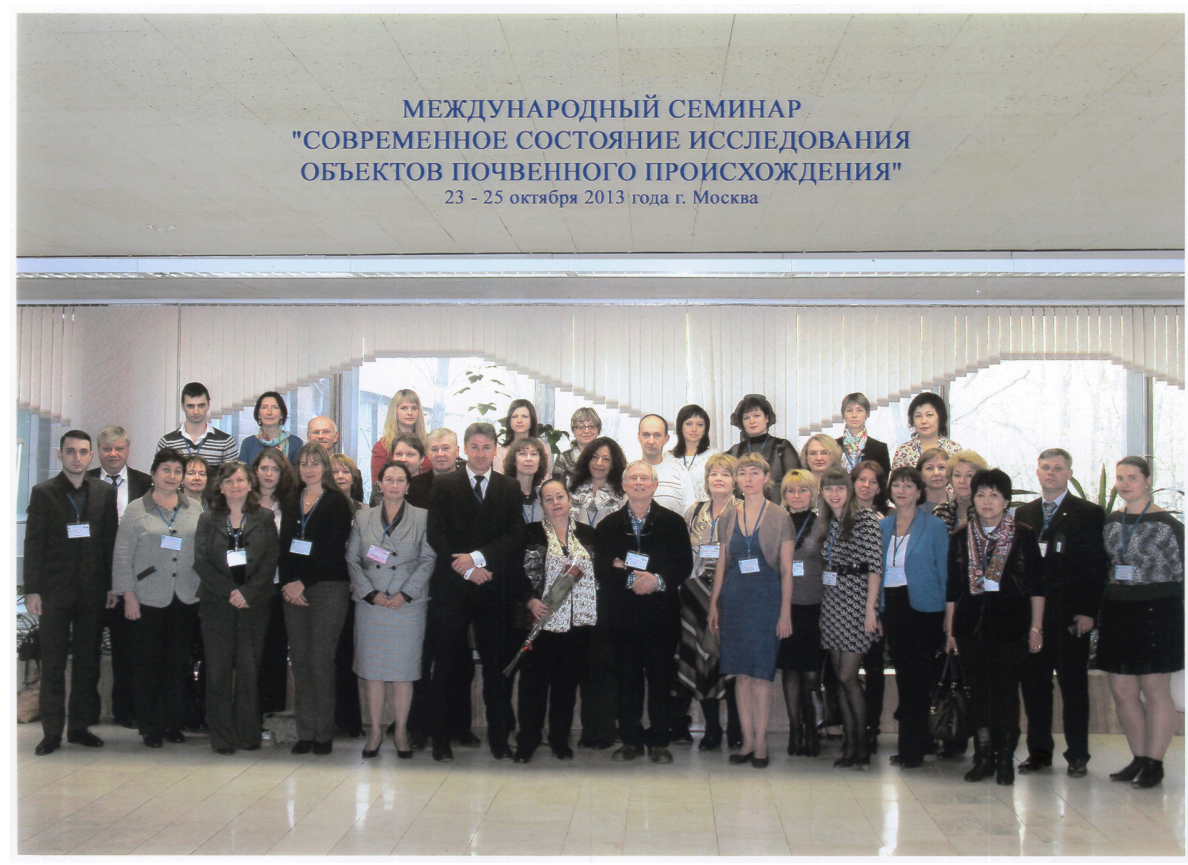

Figure 7. IUGS-IFG knowledge transfer and capacity building with the Russian Federal Centre for Forensic Science, Ministry of Justice, Moscow (Source: Dr. Olga Gradusova, Dr. Ekaterina Nesterina RFCFS, and IUGS-IFG Annual Report for 2013). the first international event of its kind to be hosted in Russia and the Commonwealth of Independent States (CIS) to specifically focus on soil forensics and forensic geology. It was attended by the Ministry of the Interior of Russia, the Police Service, Investigative Committee of Russia, Federal Drug Control Service of Russia and the Federal Security Service of Russia. Delegates were invited from Armenia, Australia, Azerbaijan, Belarus, Israel, Italy, Kazakhstan, Kyrgyzstan, Latvia, Netherlands, Northern Ireland, UK, Ukraine and USA (Fig. 7).

\section{Training}

IUGS-IFG provides a bespoke team comprising of 4 to 6 internationally recognised experts specially to deliver a focused trained programme. These usually comprise a series of formal lectures followed by practical session. When required, advanced forensic geology training courses have been provided. Training has been provided for organisations that include the following (Figs. 8 and 9):

- Underwater search in the Netherlands;

- Forensic geology for the Servicio de Criminalística of Guardia Civil, Madrid, Spain;

- Several UK Police forces, including the National Crime Agency (formerly Serious Organised Crime Agency (SOCA) and National Policing Improvement Agency (NPIA));

- Forensic geology and missing persons searches, Federal Police \& University Nacional, Bogota, Colombia;

- Ground searches, Australian Federal Police (AFP), Victoria Police, Brisbane \& Victoria, Australia;

- Geological trace evidence, Russian Fed-
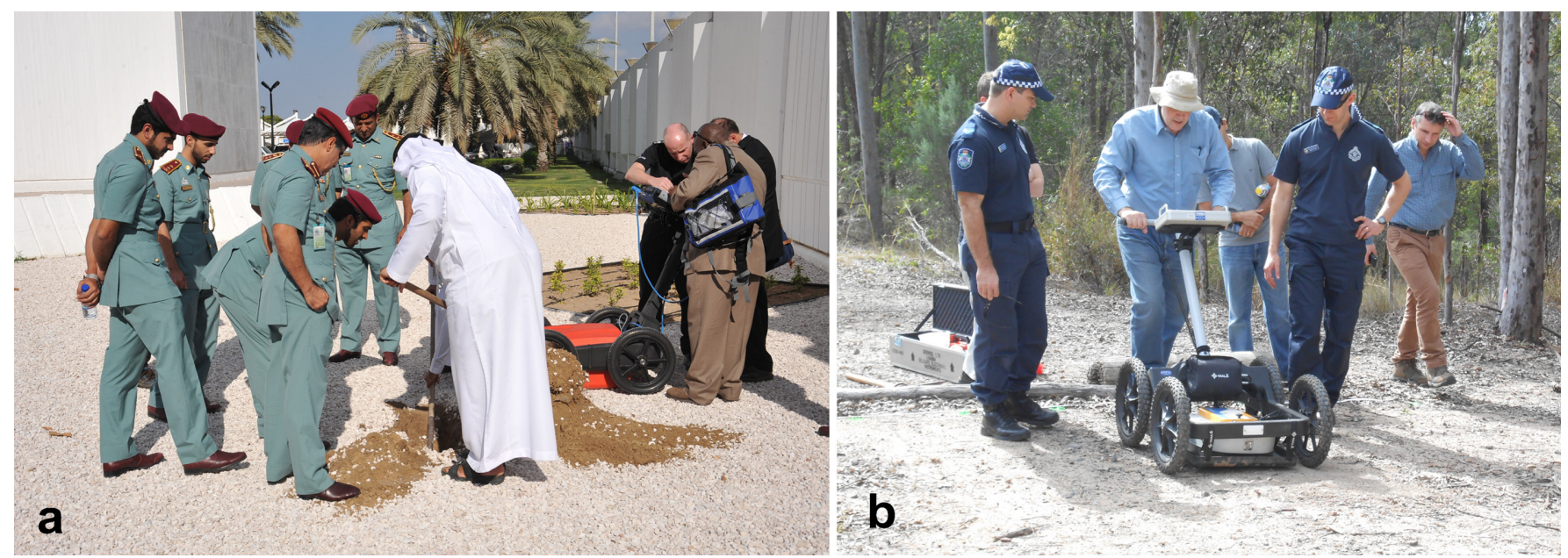

Figure 8. IUGS-IFG knowledge transfer \& training with the Abu Dhabi Police (a) and Australian Federal Police (b) (Photos: Laurance Donnelly). 


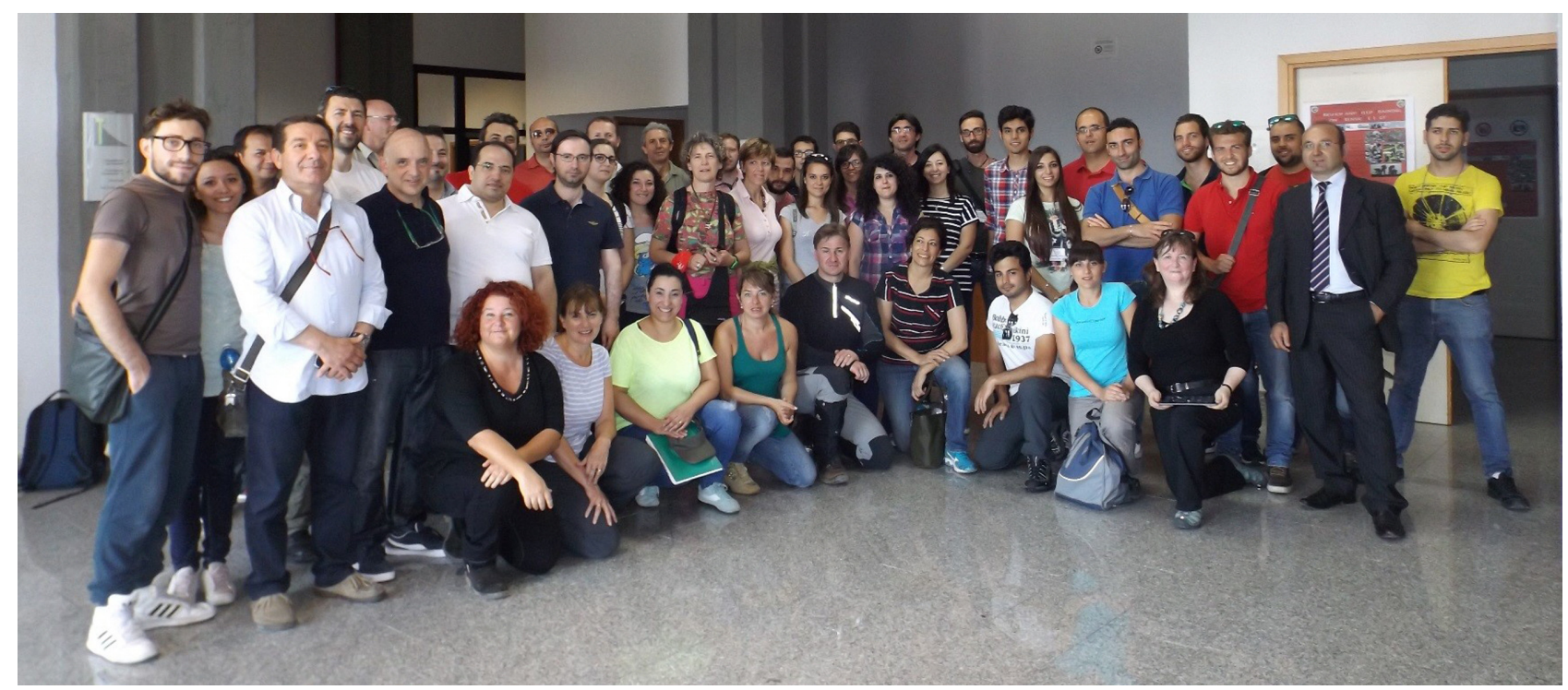

Figure 9. IUGS-IFG with staff and delegates from the MSc in Forensic Geology, University of Messina, Sicily, Italy (Photo: University of Messina and IUGS-IFG Annual Report for 2015).
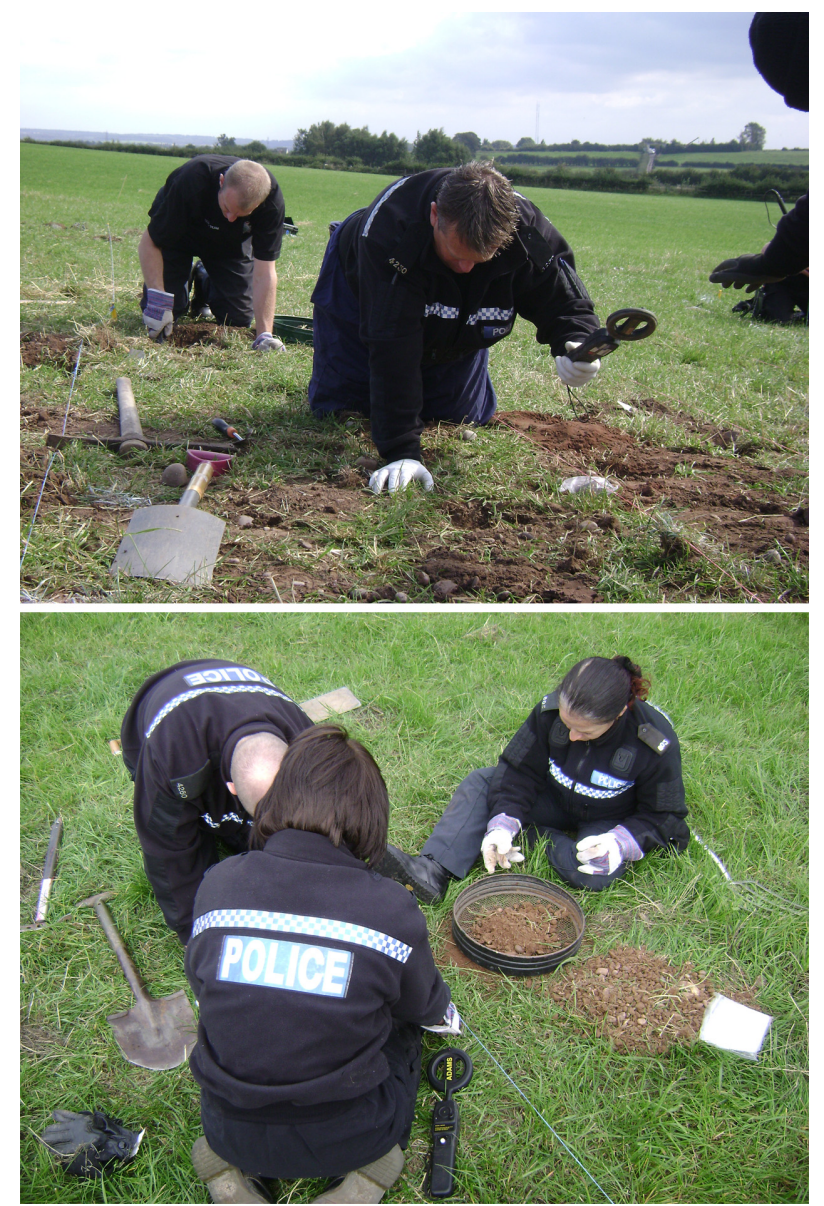

Figure 10. Forensic geology operational support for a ground search (Photos: Laurance Donnelly, in Donnelly, 2013).

eral Centre of Forensic Science, Ministry of Justice, Moscow, Russia;

- Heavy Mineral School, University of Milan, Italy;

- Searches for burials, Brazilian Federal Police, Brazil;
- Forenisc geology, land searches and marine searches, Forensic Geology Group, Abu Dhabi Police, UAE; and

- Ground search and trace evidence, Polizia \& Carabinieri, Sicily, Italy.

\section{Police Operational Case Support}

IUGS-IFG committee members have been invited to become registered with police for the provision of forensic geology services. Although this was not one of the original incentives for setting up the group, the unique experiences within IUGS-IFG has played an important role and made significant contributions to a number of high profile criminal investigations around the world (Fig. 10).

\section{Publications}

Members of IUGS-IFG and others have either authored, co-authored, edited or contributed to many forensic geology publications. This has included several text books (Murray and Tedrow, 1992; Pye, 2007; Ruffell and McKinley, 2008; Ritz et al., 2009; Murray, 2011; Bergslien, 2012; Di Maggio et al., 2013), two Geological Society of London Special Publications (Pye and Croft, 2004; Pirrie et al., 2013). Numerous papers have also been published in peer reviewed scientific journals, conference proceeding, popular press and magazine articles.

\section{Acknowledgements}

The author would like to thank the IUGS Executive Committee for supporting the Initiative on Forensic Geology (IFG). Dr. Peter Bobrowsky and Mr Brain Marker, MBE, are also gratefully acknowledged for their continued support to IUGS-IFG and encouragement for the production of this themed issue on forensic geology. The co-authors and are thanked for their contributions and reviews. 


\section{References}

Bergslien, E., 2012, An introduction to forensic geoscience: Wiley-Blackwell, Chichester, $514 \mathrm{p}$.

Campbell, M., 2007, Sherlock Holmes: Pocket Essentials: Harpenden, Herts, $160 \mathrm{p}$.

Calvo, J., 2016, International Union of Geological Sciences (IUGS), Ad Hoc Review of Initiative on Forensic Geology (IFG): Episodes, v. 39, no. 3, pp. 535-537.

Di Maggio, R.M., Barone, P.M., Pettinelli, E., Mattei, M., Lauro, S., and Banchelli, A., 2013, Geologia forense. Introduzione alle geoscienze applicate alle indagini giudiziarie: Dario Flaccovio Editore, Palermo, $320 \mathrm{p}$.

Donnelly, L.J., 2013, The design and implementation of a high assurance forensic geology and police search to verify total gold recovery following the discovery of the Staffordshire (Anglo Saxon) gold hoard. in Pirrie, D., Ruffell, A. R., and Dawson, L. (eds.), Environmental and Criminal Geoforensics: Geological Society of London, Special Publication, 384, pp. 195-208.

Donnelly, L.J., 2011, International Union of Geological Sciences (IUGS), Commission on Geosciences for Environmental Management (GEM), Report on Working Group on Forensic Geology (WGFG) and Establishment of the IUGS Initiative on Forensic Geology: Submitted to $62^{\text {nd }}$ Executive Committee of the IUGS. UNESCO Headquarters, Paris, France, Tuesday 22nd February 2011.

Donnelly, L.J., 2010, The role of geoforensics in policing and law enforcement: Emergency Global Barclay Media Limited, January 2010, pp. 19-22.

Donnelly, L.J., 2009, Establishment of the IUGS-GEM working group forensic geology: Submitted to the International Union of Geological Sciences, Commission for Geoenvironmental Management, $6^{\text {th }}$ Annual Business Meeting of IUGS-GEM, Montevideo, Uruguay, October 1213, 2009.

Donnelly, L.J., 2008, Considerations for a working group forensic geology: Submitted to the International Union of Geological Sciences, Commission for Geoenvironmental Management, $5^{\text {th }}$ Annual Business Meeting of IUGS-GEM Oslo, Norway, August 8-9, 2008.

Donnelly, L.J., 2006, First inaugural meeting of the Geological Society of London, Forensic Geoscience Group. Geoscientists at Crime Scenes. Forensic Geoscience Group Meeting, Geological Society of London, Burlington House, 20 December 2006.

Donnelly, L.J., 2005, Considerations for a Geological Society of London
Forensic Geology Specialist Group: Submitted to the Geological Society of London, Executive Secretary and Science Council, December 2005.

Donnelly, L.J., 2003, The applications of forensic geology to help the police solve crimes. European Geologist: Journal of the European Federation of Geologists, v. 16, pp. 8-12.

Donnelly, L.J., 2002, Finding the silent witness: Geoscientist, v. 1, no. 5, pp. 16-17: How forensic geology helps solve crime. All-Party Parliamentary Group for Earth Science, Westminster Palace, House of Commons, March 12, 2002.

Donnelly, L.J., and Harrison, M., 2015, A Collaborative Methodology for Ground Searches by a Forensic Geologist and Law Enforcement (Police) Officer: Detecting Evidence Related to Homicide, Terrorism and Organized Crime: Proceedings of the $3^{\text {rd }}$ International Conference on Engineering Geophysics, Session on Forensic Geosciences, Al Ain, FG02, pp. 260-268.

Donnelly, L.J., 2011, International Union of Geological Sciences (IUGS), Commission on Geosciences for Environmental Management (GEM), Report on Working Group on Forensic Geology (WGFG) and Establishment of the IUGS Initiative on Forensic Geology: $62^{\text {nd }}$ Executive Committee of the IUGS, UNESCO Headquarters, Paris, February 22, 2011.

Harrison, M., 2008, How can geologists aid the understanding of a crime scene? Police Professional Investigative Practice Journal, v. 22, pp. $20-22$.

Murray, R., 2011, Evidence from the Earth : Forensic Geology and Criminal Investigation ( $2^{\text {nd }}$ edition): Mountain Press, Missoula, $201 \mathrm{p}$.

Murray, R., and Tedrow, J., 1992, Forensic Geology: Prentice Hall, New York, $203 \mathrm{p}$.

Pirrie, D., Ruffell, A., and Dawson, L.A. (eds.), 2013, Environmental and criminal geoforensics: Geological Society of London, Special Publication, v. 384, 273 p.

Pirrie, D., Donnelly, L.J., Rollinson, G.K., Butcher, A.R., and Dawson L.A., 2013, Forensic geology at the International School Science Fair 2013: Geology Today, v. 29, no. 6, pp. 222-228.

Pye, K., 2007, Geological and soil evidence: forensic applications: CRC Press, Boca Raton, $356 \mathrm{p}$.

Pye, K., and Croft, D. (eds.), 2004, Forensic geoscience, principles, techniques and applications: Geological Society of London, Special Publication, v. 232,318 p.

Ritz, K., Dawson, L.A., and Miller, D. (eds.), 2009, Criminal and environmental soil forensics: Springer, Berlin, $519 \mathrm{p}$.

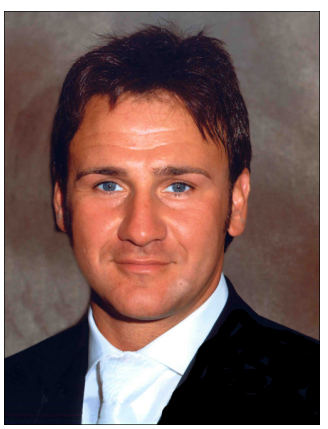

Laurance Donnelly is a professional, chartered, geologist with a first class honours degree (BSc) in Applied Geology and Ph.D. in Geohazards. He has 27 years of international experiences in; mineral exploration, mining geology, engineering geology, geohazards and forensic geology. He has pioneered new ground search strategies for graves and other burials related to homicide, serious organised crime and terrorism. He has also advised the police on cases involving geological trace evidence. He is registered as an Expert Adviser with the UK National Crime Agency. He is the founder of the IUGS Initiative on Forensic Geology and Geological Society of London, Forensic Geoscience Group. 